Available online on 30.08.2019 at http://jddtonline.info
Journal of Drug Delivery and Therapeutics
(c) 2011-18, publisher and licensee JDDT, This is an Open Access article which permits unrestricted
non-commercial use, provided the original work is properly cited

Open $\odot$ Access

Research Article

\title{
Growth of Grass Carp Ctenopharyngodon idella Fed on Hybrid Napier Grass (CO-3) Mixed Diet
}

\section{S. Sangeetha* and Dr. K. Rajendran,}

P.G. and Research Department of Zoology and Biotechnology, A.V.V.M. Sri Pushpam College (Autonomous), Poondi-613 503, Thanjavur district, India

\begin{abstract}
The study was performed to examine the efficiency of hybrid napier grass (CO-3) mixed diet on growth performance of freshwater fish Ctenopharyngodon idella. Alive grass carp fingerlings were collected from commercial fish farm in Thanjavur from June 2015 to May 2016. Fishes were divided into two groups and acclimated for 7 days before feeding trial. The fishes were fed with control and experimental diet. The growth parameters such ABW, ABL, BWG and SGR were thoroughly studied adopting standard procedure. The result of the study clearly indicates that there was a significant variation in growth of control and experimental fishes. The fish fed with CO-3 grass mixed diet showed elevated level in body weight, body length, weight gain and specific growth rate. This study suggests that the CO-3 grass mixed diet is more suitable for grass carp aquaculture practice.
\end{abstract}

Keywords: Hybrid Napier grass, CO-3, Ctenopharyngodon idella, Specific growth rate.

Article Info: Received 12 July 2019; $\quad$ Review Completed 17 August 2019; $\quad$ Accepted 21 August 2019; Available online 30 Aug 2019

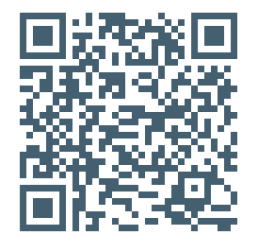

\section{Cite this article as:}

Sangeetha S, Rajendran K, Growth of Grass Carp Ctenopharyngodon idella Fed on Hybrid Napier Grass (CO-3) Mixed Diet, Journal of Drug Delivery and Therapeutics. 2019; 9(4-A):151-154 http://dx.doi.org/10.22270/jddt.v9i4-A.3432

\section{*Address for Correspondence:}

Poondi-613 503, Thanjavur district, India

\section{INTRODUCTION}

Grass Carp is one of the most important herbivorus fish, which are rich in protein and omega- 3 fatty acids. It can be cultured in mono or polyculture technique with other carps. It feeds on supplementary formulated feed. Protein is most expensive component in fish feed, and most important factor which promote the growth of fishes [18]. The natural food, green forage, grasses and plant materials which provide highest amount of protein, variety of vitamins, and amino acids required for the growth of grass carp [6, 19]. So addition of grasses and new substances to the compound feed improve the flesh quality and promote the growth of fishes $[5,11,12]$. Feed additives with bioactive components in diets increase the growth performance of fishes $[2,3,9$, 22]. The plant with phytochemicals which improve the survival and growth of fishes [15, 16, 20, 21, 25]. Hybrid Napier grass (CO-3) was developed by Tamil Nadu Agricultural University, Coimbatore, India in 1997. It is an inter specific hybrid between Pennisetum purpureum Schum. and Pennisetum americanum L. It is rich in crude protein content, fibre content, dry matter, high yielding potential, quick regeneration capacity, high palatability, etc. [17]. Mixture of green forage and compound feed could reduce body cavity fat improve body shape and promote the growth of grass carp [4, 8, 10,13,14]. Grass carp fed with hybrid napier grass had growth rates three and five times higher than those fed with hydrilla and ceratophyllum respectively $[23,24]$. So the superior quality of the CO-3 grass especially in crude protein has great potential for adding to compound feed in the diet of grass carp and it highly promote the growth of grass carp.

\section{MATERIALS AND METHODS}

Alive freshwater grass carp Ctenopharyngodon idella fingerlings $(50 \mathrm{~g})$ were collected from June 2015 to May 2016 at Himalayan fish farm near Thanjavur, Tamil Nadu, India. The fishes were brought to laboratory in alive condition acclimated and reared in glass tank $(15 \times 90 \times 60$ $\mathrm{cm}$ ) for 7 days. The fishes were grouped into two groups namely control and experimental group each group consists of 20 fishes. The fish were fed $10 \%$ of the body weight daily, which was split into two equal rations in the morning and evening. The control group of fishes fed with formulated CODEN (USA): JDDTAO 
feed and experimental group of fishes fed with CO-3 powder mixed diet. Continuous aeration was done with help of aerator. The water in both aquaria were changed every alternate days. The feeding trial were conducted for 60 days in replicate.

In the present study for the preparation of experimental diet and phytochemical analysis the plant $\mathrm{CO}-3$ was collected from dairy farm Eachankottai, Thanjavur district, Tamil Nadu, India. The plant samples were brought to the laboratory, clean and shade dried for a week. The dried plant were powdered by tissue homogenizer and passed through $20 \mu$ mesh sieve. The powder were used for preparation of experimental diet and phytochemical studies. The extract was prepared by using organic solvents such as methanol and chloroform. The concentrated extract were kept in refrigerator at $4^{\circ} \mathrm{C}$ until further use. The phytochemical screening of various fractions from methanolic and chloroformic extract of $\mathrm{CO}-3$ were carried out by using standard procedure (AOAC method, 1995).

\section{Preparation of control and experimental diet}

The common ingredients in control diet were rice bran, groundnut oil cake, fish meal, wheat flour, tapioca flour and vitamin and mineral mix. The ingredients were ground well to a fine-powder and mixed thoroughly with water to get smooth dough. This was extruded through a pellitizer, the pellets were dried and then stored in dry air tight container at $28^{\circ} \mathrm{C}$. The experimental diet was prepared along with formulated feed ingredients 10 per cent of $\mathrm{CO}-3$ plant powder was added and pellets were prepared and stored.

\section{Growth parameters}

In the present investigation, the growth performance of the fish was evaluated using Halver's procedure (1972). The fishes in control and experimental tanks, weighed individually and separately nearest $0.1 \mathrm{mg}$ at 10 days intervals, the entire period of 60 days of feeding trial. The length of the fish was measured by using Vernier Calliber. The fishes were weighed with help of top pan balance. From the data, the average length and weight of the fishes were calculated and other parameters were determined by using the following formula.

$$
\begin{gathered}
\text { Body weight gain }(\mathrm{BWG})=\frac{\text { Final weight }- \text { Initial weight }}{\text { Initial weight }} \times 100 \\
\text { In (Final weight }- \text { Initial weight) }
\end{gathered}
$$

Specific growth rate $(\mathrm{SGR})=$

Number of days

\section{RESULT}

In the present study, the percentage of fish feed ingredients used in control and experimental diet are given in the table 1. In both control and experimental diet the fish feed ingredients were rice bran, groundnut oil cake, fish meal, wheat flour, tapioca flour, vitamin and mineral mixture used in different percentage, but in experimental diet in addition to above ingredients $\mathrm{CO}-3$ powder $(10 \%)$ was added. The proximate composition of feed ingredients were analysed and given in the table 2. From the table protein, carbohydrate, fat and ash content of various feed ingredients significantly varied. The proximate composition of control and experimental diet showed a slight variation. The variation may be due to the adding of $\mathrm{CO}-3$ powder in experimental diet.

The result of phytochemical screening of methanolic and chloroformic extract of $\mathrm{CO}-3$ indicates the presence of primary and secondary metabolites such as protein, carbohydrates, fat, reducing sugar, amino acids, alkaloids, flavonoids, anthroquinone, anthocyanin, benzaconone, qnercetin, coumarins, Ephedrine, Glycosides, Kaemferol, Phenol, Myricetin, Phlobatannins, Phytosteroides, Saponin, terpenoids and tannins. The presence of lot of primary and secondary metabolites in CO-3 significantly increased the growth of grass carp C. idella fed with experimental diet.

The growth performance of grass carp Ctenopharyngodon idella exposed to control and experimental diet is given in the table 3 . The weight and length of the fish were used as measures of growth. The growth performance of $C$. idella showed a significant variation in control and experimental diet. An elevated growth rate was recorded when the fish fed with CO-3 mixed diet than control diet during experimental

\begin{tabular}{|c|c|c|c|c|c|c|}
\hline \multirow[b]{2}{*}{ Ingredients } & \multicolumn{2}{|c|}{ Proportions } & \multicolumn{4}{|c|}{ Proximate composition } \\
\hline & $\begin{array}{c}\text { Control feed } \\
(\%)\end{array}$ & $\begin{array}{c}\text { Experimental feed } \\
(\%)\end{array}$ & Protein $(\%)$ & Fat $(\%)$ & $\begin{array}{c}\text { Carbohydrate } \\
(\%)\end{array}$ & Ash (\%) \\
\hline Rice bran & 40 & 35 & 7.43 & 4.08 & 11.79 & 13.28 \\
\hline Groundnut oil cake & 30 & 25 & 48.97 & 11.69 & 8.56 & 9.04 \\
\hline Fish meal & 15 & 15 & 54.22 & 12.13 & 9.42 & 21.65 \\
\hline Wheat flour & 7 & 7 & 16.37 & 8.59 & 6.91 & 7.49 \\
\hline Tapioca flour & 7 & 7 & 9.16 & 5.74 & 7.08 & 4.17 \\
\hline $\begin{array}{l}\text { Vitamin mineral mix } \\
\text { (powder) }\end{array}$ & 1 & 1 & - & - & - & - \\
\hline CO-3 grass (powder) & - & 10 & 32.71 & 5.02 & 7.94 & 15.91 \\
\hline
\end{tabular}
period.

Table 1. Proportions and proximate composition of feed ingredients 
Table 2. Composition of control and experimental diet

\begin{tabular}{|l|c|c|c|c|c|c|c|c|}
\hline \multirow{2}{*}{ Ingredients } & \multicolumn{4}{|c|}{ Control feed (\%) } & \multicolumn{4}{c|}{ Experimental feed (\%) } \\
\cline { 2 - 10 } & $\begin{array}{c}\text { Protein } \\
(\%)\end{array}$ & $\begin{array}{c}\text { Fat } \\
(\%)\end{array}$ & $\begin{array}{c}\text { Carbohydrat } \\
\text { e (\%) }\end{array}$ & $\begin{array}{c}\text { Ash } \\
(\%)\end{array}$ & Protein (\%) & Fat (\%) & $\begin{array}{c}\text { Carbohydrat } \\
\text { e (\%) }\end{array}$ & Ash (\%) \\
\hline Rice bran & 2.97 & 1.63 & 4.72 & 5.31 & 2.60 & 1.43 & 4.13 & 4.65 \\
\hline Groundnut oil cake & 14.69 & 3.51 & 2.57 & 2.71 & 12.24 & 2.92 & 2.14 & 2.26 \\
\hline Fish meal & 8.13 & 1.82 & 1.41 & 3.25 & 8.13 & 1.82 & 1.41 & 3.25 \\
\hline Wheat flour & 1.15 & 0.60 & 0.48 & 0.52 & 1.15 & 0.60 & 0.48 & 0.52 \\
\hline Tapioca flour & 0.64 & 0.40 & 0.49 & 0.29 & 0.64 & 0.40 & 0.49 & 0.29 \\
\hline CO-3 grass (powder) & - & - & - & - & 3.27 & 0.50 & 0.79 & 1.59 \\
\hline Total & 27.58 & 7.96 & 9.67 & 12.08 & 28.03 & 7.67 & 9.44 & 12.56 \\
\hline
\end{tabular}

Table 3. Growth performance of grass carp Ctenopharyngodon idella fed with control and experimental diet

\begin{tabular}{|c|c|c|c|c|c|c|c|c|c|c|c|c|}
\hline \multirow[t]{2}{*}{ Days } & \multicolumn{2}{|c|}{ Average body weight (g) } & \multicolumn{2}{|c|}{ Average total length $(\mathrm{cm})$} & \multicolumn{2}{|c|}{$\begin{array}{l}\text { Weight increase } \\
\text { (g) }\end{array}$} & \multicolumn{2}{|c|}{$\begin{array}{c}\text { Total length } \\
\text { increase }(\mathrm{cm})\end{array}$} & \multicolumn{2}{|c|}{$\begin{array}{l}\text { Body weight } \\
\text { gain }(\%)\end{array}$} & \multicolumn{2}{|c|}{$\begin{array}{c}\text { Specific } \\
\text { growth rate } \\
(\%)\end{array}$} \\
\hline & 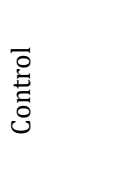 & 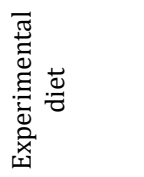 & $\begin{array}{l}\overrightarrow{0} \\
\dot{ \pm} \\
0 \\
0\end{array}$ & 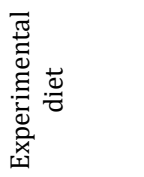 & $\begin{array}{l}\overrightarrow{0} \\
\dot{E} \\
0 \\
0\end{array}$ & 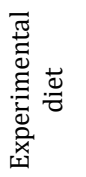 & $\begin{array}{l}\overline{0} \\
\stackrel{ \pm}{0} \\
0\end{array}$ & 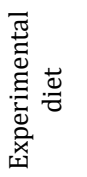 & $\begin{array}{l}\overrightarrow{0} \\
\stackrel{0}{0} \\
0\end{array}$ & 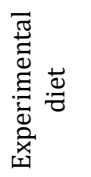 & $\begin{array}{l}\overrightarrow{0} \\
\dot{\Xi} \\
0\end{array}$ & 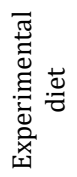 \\
\hline Initial & $\begin{array}{c}50.14 \pm \\
0.48\end{array}$ & $\begin{array}{c}50.12 \pm \\
0.51\end{array}$ & $\begin{array}{c}15.18 \pm \\
0.31\end{array}$ & $\begin{array}{c}15.20 \pm \\
0.32\end{array}$ & 00.0 & 0.00 & 00.0 & 00.0 & 00.0 & 0.00 & 0.00 & 0.00 \\
\hline $10^{\text {th }}$ & $\begin{array}{c}64.38 \pm \\
0.53\end{array}$ & $\begin{array}{c}65.97 \pm \\
0.64\end{array}$ & $\begin{array}{c}17.00 \pm \\
0.34\end{array}$ & $\begin{array}{c}17.10 \pm \\
0.35\end{array}$ & 14.24 & 15.85 & 1.82 & 1.90 & 28.40 & 31.62 & 1.08 & 1.19 \\
\hline $20^{\text {th }}$ & $\begin{array}{c}87.51 \pm \\
0.57\end{array}$ & $\begin{array}{c}89.48 \pm \\
0.76\end{array}$ & $\begin{array}{c}18.94 \pm \\
0.37\end{array}$ & $\begin{array}{c}19.19 \pm \\
0.38\end{array}$ & 23.13 & 23.51 & 1.94 & 2.09 & 35.93 & 35.64 & 1.34 & 1.33 \\
\hline $30^{\text {th }}$ & $\begin{array}{c}118.29 \pm \\
0.68\end{array}$ & $\begin{array}{c}122.56 \pm \\
0.87\end{array}$ & $\begin{array}{c}20.90 \pm \\
0.38\end{array}$ & $\begin{array}{c}21.39 \pm \\
0.41\end{array}$ & 30.78 & 33.08 & 1.97 & 2.29 & 35.17 & 36.97 & 1.31 & 1.36 \\
\hline $40^{\text {th }}$ & $\begin{array}{c}159.05 \pm \\
0.72\end{array}$ & $\begin{array}{c}165.18 \pm \\
0.94\end{array}$ & $\begin{array}{c}22.89 \pm \\
0.43\end{array}$ & $\begin{array}{c}23.79 \pm \\
0.42\end{array}$ & 40.76 & 42.62 & 1.97 & 2.40 & 34.46 & 34.77 & 1.28 & 1.29 \\
\hline $50^{\text {th }}$ & $\begin{array}{c}207.46 \pm \\
0.85\end{array}$ & $\begin{array}{c}216.79 \pm \\
0.96\end{array}$ & $\begin{array}{c}24.96 \pm \\
0.45\end{array}$ & $\begin{array}{c}26.28 \pm \\
0.47\end{array}$ & 48.41 & 51.61 & 2.07 & 2.49 & 30.47 & 31.24 & 1.15 & 1.19 \\
\hline $60^{\text {th }}$ & $\begin{array}{c}269.67 \pm \\
0.94\end{array}$ & $\begin{array}{c}284.34 \pm \\
1.04\end{array}$ & $\begin{array}{c}27.37 \pm \\
0.47\end{array}$ & $\begin{array}{c}28.79 \pm \\
0.51\end{array}$ & 62.21 & 67.55 & 2.41 & 28.79 & 29.98 & 31.16 & 1.15 & 1.17 \\
\hline
\end{tabular}

\section{DISCUSSION}

In the present investigation, the differences in growth of grass carp, Ctenopharyngodon idella could be attributed to the quality, nutritive value of diet, ingestion and digestion. The proximate composition of various fish feed ingredients significantly varied. The percentage of total protein content slightly higher than other components in both control and experimental diet. Similar observations were reported by various workers $[13,18]$. The experimental diet contain plant CO-3 powder $(10 \%)$ resulted in significant growth performance than control diet. In the present study, the increase in growth of grass carp fed with experimental diet is may be due to presence of plant materials with lot of primary and secondary metabolites. Similar observations were reported by earlier workers [2, 10, 12, 18, 20, 22]. Feeding with mixture of compound feed and green fodder control the development of fatty livers and promote the growth of fish $[8,19]$.

Luo et al. [18] stated that the protein is the most important factor affecting growth performance of fish and feed cost. New substances are added in fish feed to improve food conversion efficiency that result in fish growth [5]. Takaoka et al. [10] obtained better growth in sea bream with dietary medicinal herbs mixed diet. John et al. [11] used different plants as feed additives which enhance the growth and improved survival of Oreochromis niloticus. A significant variation in growth performance and body composition of juvenile perk perch was observed when the fish fed with medicinal herbs mixed diet [25]. Usually plant materials having lot of phytochemicals. In the present study, the plant CO-3 having lot of primary and secondary metabolites such as protein, carbohydrate, fat, amino acids, alkaloids, flavonoids etc. The present investigation agrees with earlier observations $[15,16,23]$.

Sivagurunathan et al. [21] observed that the mixing of lotus in diet improved the growth and haematology of Cirrhinus mrigala. Dietary green tea extract improved growth performance, body composition and reduce the stress of fish [9]. The plant leaves as feed ingredient showed significant variation in growth performance of Tilapia [3, 14]. Higher grass carp muscle, with high protein content and a lower crude fat content was observed when the fish fed with mixture of hybrid napier grass and compound feed $[4,17$ 24]. In the present study the grass carp fed with CO-3 mixed diet have better growth and weight gain. Hence, it suggested that plant powder mixed diet is more suitable for $C$. idella culture practice. 


\section{REFERENCES}

[1] AOAC, 1995. Association of Official Analytical Chemists Official Methods of Analysis. $16^{\text {th }}$ edn. Arlington, VA, USA: AOAC.

[2] Citarasu, T., 2010. Herbal biomedicines: a new opportunity for aquaculture industry. Aquacult. Int., 18: 403-414.

[3] Dada, A.A., and Ikuerowo, M., 2015. Effect ethanolic extract of Garcinia kola seeds on growth and haematology of Catfish, Clarias gariepinus brood stek. African Journal of Agricultural Research, 4(4): 344-347.

[4] Feng, D.Q., Huang, Q.L., Tang, L.F., Zhong, Z.M., and Huang, X.S. 2008. Effect of Pennisetum americanum $\times$ P. purpureum CV. $23 \mathrm{~A} \times \mathrm{N} 51$ on fatty acid component in grass carp muscle. Chinese Agricult. Sci. Bull. , 24(6): 487-490 (In Chinese).

[5] Fernandez-Navarro, M., Peragon, J., Esteban, F., Higuera, M. and Lupianenz, J.A., 2006. Maxlinic acid as a feed additive to stimulate growth and hepatic protein turnover rates in rainbow trout (Onchorhynchus mykiss). Comp. Biochem. Physiol. C. Toxicol. Pharamacol., 144: 130-140.

[6] Guo, J.L., Ma, H.J., Sun, L.H., Shen, B.Q., Chen, J.M., Pan, Q., and Ye, J.Y., 2012. Effects of different proportions of pelleted feed and duckweed on growth, body shape and muscle composition of grass carp (Ctenopharyngon idella). J. Zhejiang Ocean Uni. (Natural Science), 31(6): 503-508 (In Chinese).

[7] Halver, J.E. (ed.) 1972. Fish Nutrition. New York: Academic Press, p. 205.

[8] Huang, S.J., amd Huang, Q.Y., 1992. Effects of feeding green fodder and supplemental agents on growth rate and fat metabolism in grass carp (Ctenopharyngodon idellus). J. Shanghai Fish. Univ., 1(1-2): 20-26 (In Chinese).

[9] Hwang, J.H., Lee, S.W., Rha, S.J., Yoon, H.S., Park, E.S., Han, K.H., and Kim, S.J., 2013. Dietary green tea extract improves growth performance, body composition, and stress recovery in the juvenile black rockfish, Sebastes schlegeli. Aquacult. Internat., 21: 525-538.

[10] Ji, S., Takaoka, O., Jeon, G., Lee, S., Ishumaru, K., Seoka, M., and Takii, K., 2007. Dietary medicinal herbs improve growth and some non specific immunity of red sea bream, Pagrus major. Fish Sci., 73(1): 63-69

[11] John, G., Mesalhy, S., Rezk, M., El-Naggar, G., and Fathi, M., 2007. Effect of some immunostimulants as feed additives on the survival growth performance of Nile tilapia, Oreochromis niloticus and their response to artificial infection. Egypt $J$ Aquat. Biol. Fish, 11(3): 1299-1308.

[12] Johnson, C., and Banerji, A., 2007. Influence of extract isolated from the plant Sesvium portulacastrum on growth and metabolism in freshwater teleost, Labeo rohita (Rohu). Fishery Tech., 44(2): 229-234.

[13] Kaleeswaran, B., Ilavenil, S., and Ravikumar, 2011. Growth response, feed conversion ratio and antiprotease activity of
Cynodon dactylon mixed diet in Catla catla (Ham.). J. Anim. Vet. $A d v ., 10(4):$ 511-517.

[14] Karpagam, B., and Krishnaveni, N., 2014. Effect of supplementation of selected plant leaves as growth promoters of Tilapia fish (Oreochromis mossambicus). Res. J. Recent Sci., 3: 120-123.

[15] Kasarkar, A.R., Thakur, M.S., Chougale, S.S., Wndkar, S.S., Jadhav, S.B., Patil, S.A., and Kubal, S.B., 2017. Preliminary phytochemical investigation of the leaves of Cynodon dactylon (L.) Cyperus rotundus L. and Typha angustifolia L. J. Med. Plants Studies, 5(4): 203-205.

[16] Dineshkumar, and Rajakumar, R., 2015. GC-MS evaluation of bioactive molecules from the methanolic leaf extract of Azadirachta indica (A.Juss). Asian Journal of Pharmaceutical Science and Technology, 5(2): 64-69.

[17] Lowe, K.F., 2011. Forage and pastures: perennial forage and pasture crops-species and varieties. In: Encyclopedia of Diary Sciences (Second Edition).

[18] Luo, Z., Liu, Y.J., Maik, K., Tian, L.X., Liu, D.H., and Tan, X.Y., 2004. Optimal dietary protein requirement of grouper Epinephelus coioides juveniles fed isoenergetic diets in floating net cages. Aqua. Nutr., 10: 247-252.

[19] Raa, J., Gilberg, A., and Olley, J.N., 1982. Fish silage: a review. Crit. Rev. Food Sci., 16(4): 383-419.

[20] Rawling, M.D., Merrifield, D.L., and Davies, S.J., 2009. Preliminary assessment of dietary supplementation of Sangrovit $₫$ on red tilapia (Oreochromis niloticus) growth performance and health. Aquacult., 294: 118-122.

[21] Sivagurunathan, A., Innocent, B.X., and Muthulakshmi, S., 2012. Immunomodulatory effect of dietary Nelumbo nucifera (Lotus) in growth and haematology of Cirrhinus mrigala Chattarged with Pseudomonas aeruginosa. J. Appl. Pharm. Sci., 2: 191-195.

[22] Turan, F., 2006. Improvement of growth performance in tilapia (Oreochromis aureus Linn.) by supplementation of red clover Trifolium pretense in diets. Israel J. Aquacult., 58: 34-38.

[23] Venkatesh, B., and Shetty, H.P.C., 1978. Studies on the growth rate of the grass carp Ctenopharyngodon idella (Valenciennes) fed on two aquatic weeds and a terrestrial grass. Aquaculture, 13: $45-53$

[24] Yu, E.M., Li, X.Y., Xie, J., Chen, Z.H., Wang, G.J., Yu, D.G., Li, Z.F., Xia, Y., and Zhang, K., 2018. A New Culture Method of High Ecological Efficiency of Grass Carp (Ctenopharyngodon idellus). Nat. Environ. Poll. Technol., 17(1): 299-305.

[25] Zakes, Z., Kowalska, A., Demska-Zakes, K., Jeney, G., and Jeney, Z., 2008. Effect of two medicinal herbs (Astragalus radix and Lonicera japonica) on the growth performance and body composition of juvenile perk perch (Sander lucioperca). Aquacult., 30: 1149-1160. 